\title{
EVIDENCE OF DAILY AND SEASONAL INVERSIONS OF AIRFLOW IN PETITES DALES CAVE, NORMANDY, FRANCE
}

\author{
DNEVNI IN SEZONSKI OBRATI SMERI ZRAČNEGA TOKA \\ V JAMI PETITES DALES, NORMANDIJA, FRANCIJA
}

\author{
Laurent MAGNE ${ }^{1}$, Nicolas LECOQ ${ }^{2, *}$, Joel RODET ${ }^{3}$, Stéphane CHEDEVILLE ${ }^{4}$ \& Jean-Pierre VIARD ${ }^{5}$
}

\begin{abstract}
UDC 551.584:551.442(442.1/.5)

Laurent Magne, Nicolas Lecoq, Joel Rodet, Stéphane Chedeville \& Jean-Pierre Viard: Evidence of daily and seasonal inversions of airflow in Petites Dales cave, Normandy, France A detailed study of the microclimate of Petites Dales karst cave with single-entrance is presented in this paper. Two years of cave monitoring investigate temperature, weight of water vapour and airflow distributions outside and inside the cavity to determine the global behaviour of the karst cave. In addition, daily measurements of temperature and airflow demonstrate clearly the stratification of the air and inversions of the airflow during day-time. The cave air is intensively exchanged with external air during the years, with two main modes: (i) airflow enters from the ceiling during summer period and (ii) airflow enters from the floor during winter. At the entrance, an Sshaped velocity profile was observed and far from the entrance, convection loops were observed. During the other period of the year, the airflows may switch from top to bottom or conversely. The thermodynamic conditions of switching are discussed in this paper. This study provided for the first time evidence of daily airflow inversion. Study of cave climates is required in the comprehension of cave flora and fauna, thermodynamic conditions for karst processes underground, hydrogeological features of speleothems, human impact when caves are visited.

Key words: cave, microclimate, karst, airflow, temperature, variability.
\end{abstract}

Izvleček UDK 551.584:551.442(442.1/.5)

Laurent Magne, Nicolas Lecoq, Joel Rodet, Stéphane Chedeville \& Jean-Pierre Viard: Dnevni in sezonski obrati smeri zračnega toka v jami Petites Dales, Normandija, Francija

$\mathrm{V}$ članku poročamo o podrobni mikroklimatski študiji v jami Petites Dales. V jami z enim samim vhodom smo dve leti opazovali temperaturo, vlago in porazdelitev zračnih tokov. Podrobne dnevne meritve temperature in zračnega toka kažejo na stratifikacijo in dnevni obrat smeri toka. Poleti zunanji zrak vdira v jamo pri stropu, pozimi pa pri tleh. Pri tem se pri vhodu oblikuje profil hitrosti zraka v obliki črke S, globlje v jami pa konvekcijska zanka. V vmesnih obdobjih lahko pride do preklapljanja iz dotoka pod stropom $\mathrm{v}$ dotok pri dnu in obratno, kar v članku obravnavamo $\mathrm{z}$ vidika termodinamike. $\mathrm{V}$ tej raziskavi smo prvič pojasnili dnevne obrate smeri zraka v primerljivih jamah. Študije jamske mikroklime so pomembne za razumevanje jamskega ekosistema, procesov $\mathrm{v}$ jamah ter človekovega vpliva nanje.

Ključne besede: jama, mikroklima, kras, zračni tok, temperatura, spremenljivost.

\footnotetext{
${ }^{1}$ L. Magne, CNEK, 76450 Saint-Martin-aux-Buneaux, France, e-mail: lmin.ber@gmail.com

${ }^{2}$ N. Lecoq ${ }^{\star}$, Normandy University, UMR CNRS 6143 M2C, University of Rouen, 76821 Mont-Saint-Aignan cedex, France, and CNEK, 76450 Saint-Martin-aux-Buneaux, France, e-mail: nicolas.lecoq@univ-rouen.fr

${ }^{3}$ J. Rodet, Normandy University, UMR CNRS 6143 M2C, University of Rouen, 76821 Mont-Saint-Aignan cedex, France, and CNEK, 76450 Saint-Martin-aux-Buneaux, France, e-mail: joel.rodet@univ-rouen.fr

${ }^{4}$ S. Chedeville, Normandy University, UMR CNRS 6143 M2C, University of Rouen, 76821 Mont-Saint-Aignan cedex, France and CNEK, 76450 Saint-Martin-aux-Buneaux, France and University of Montpellier 2, UMR 5569 Hydrosciences, Montpellier, France, e-mail: stephane.chedeville@univ-montpellier.fr

${ }^{5}$ J.P. Viard, CNEK, 76450 Saint-Martin-aux-Buneaux, France, jeanpierreviard@orange.fr

${ }^{*}$ Corresponding Author
}

Received/Prejeto: 31.12 .2016 


\section{INTRODUCTION}

Cave temperature variability and air circulation are important phenomena that influence various karst aspects via controlling the cave microclimate. In contrast to outside climatic conditions, caves generally exhibit relatively constant temperatures and high humidity. However, the microclimatic behaviour of caves is neither static nor constant (Wigley \& Brown 1971; De Freitas et al. 1982; Michie 1984; Badino 2004, 2010). Caves are very complex both structurally and environmentally, resulting in a more differentiated environment between the outside and the inside of the cave system. The cave environment can vary significantly, both temporally and spatially (e.g. Davies 1969; De Freitas et al. 1982; Gamble et al. 2000).

Significant microclimatic variations may occur within a specific zone (generally the entrance), as well as along the total extent (Cropley 1965; De Freitas et al. 1982). The degree of variation depends largely on the structure and physical characteristics of the cave with conditions becoming more stable with distance from entrances (Gillieson 1996; De Freitas \& Littlejohn 1987). Multiple entrance caves have complicated microclimate conditions due to exchanges with the external environment via ventilation (e.g. Wigley \& Brown 1971; Tuttle \& Stevenson 1978; Bögli 1980; De Freitas \& Littlejohn 1987; Lismonde 2002).

The temperature of a cave is generally considered the same as the mean annual surface temperature (MAST) at the cave's elevation (Moore \& Sullivan 1978). A comparison of measurements made in 54 Arizona caves (Buecher 1977) indicates that the caves temperatures are in accordance with the mean annual local surface temperature. However, many exceptions are reported, e.g. Castleguard Cave, Canada (Atkinson et al. 1983), Obir Cave, Austria (Spötl et al. 2005) and St Michaels Cave, Gibraltar (Mattey et al. 2008, 2010, 2013). These anomalies are caused by dynamic ventilation and/or by geothermal flux and/or or by heat transfer from water (Baker \& Fairchild 2012).

Nevertheless, in the literature, a cave is classically divided into three separate environments with different temperatures (Poulson \& White 1969; Perry 2013):

- the highly variable twilight zone near the entrance;

- a middle zone of complete darkness and variable temperature; and

- a zone of complete darkness and constant temperature in the deep interior.

Using the definition of Luetscher \& Jeannin (2004) and Luetscher et al. (2008), temperature profiles in caves can be divided into two primary zones, the heterothermic zone near the entrance (which regroups the two previous environments) and the homothermic zone in the deep zone.
The heterothermic zone occurs from the entrance to around $150 \mathrm{~m}$ inside. It is assumed that temperatures in the heterothermic zone are controlled by heat fluxes related to water and/or air circulation, and thermal exchanges with walls. The influence of outside weather conditions may extend for several hundred metres into caves which have streams of airflow (Cropley 1965). Within the heterothermic zone, there is generally a temperature and moisture gradient, where air characteristics change from the outside conditions to reach equilibrium with the cave rock (De Freitas \& Littlejohn 1987).

The homothermic zone is characterized by high temperature stability. Inversions of temperature gradients are not observed. Badino (1995) demonstrated the major role played by the rock heat capacity in this remarkable stability. Measurements have shown that rock, air and water are almost in thermal equilibrium although water and rock temperatures are always slightly lower than air (Jeannin 1991). In the absence of complicating factors such as airflow, temperature in the homothermic zone of caves is generally a reflection of the MAST (Poulson \& White 1969; Wigley \& Brown 1971; Luetscher et al. 2008; Liñán \& del Rosal 2015).

The role of the air movement in cave atmosphere can be observed in the variation streamlines and spatial differentiation of air and surficial rock temperature (Jernigan \& Swift 2001). According to their ventilation mode, caves were historically classified into two groups: (i) static caves (single-entrance caves), and (ii) dynamic caves (multientrance caves) (Geiger 1961; Bögli 1980; Faimon et al. 2012). This classification is obsolete for many authors (Lismonde 2002; Perry 2013). Cave air circulation is nowadays classified into 5 types: cave breathing; wind-induced flow; convection; water-induced flow and chimney circulation (Fairchild \& Baker 2012; Lismonde 2002, 2005).

Cave breathing is observed in caves where entrance passages are relatively narrow compared to total cave volume. Cave breathing results from large synoptic driven barometric pressure differences between the inside and outside environment. This effect is common in single entrance caves and is more pronounced in large volume caves.

Wind-induced flow is dependent on external airflow direction, the surface landscape and the geometry of the cave. Convection occurs in descending or ascending caves and in wide and high cave chambers. Waterinduced flow involves air circulation forced by cave streams. Chimney circulation occurs in multi-entrance caves and depends upon air density differences (Wigley \& Brown 1971), with temperature being the main factor influencing air density. In cases where inner cave air tem- 
perature is higher than outside air temperature, airflow enters into caves from the lower entrance and discharge from upper entrances (the chimney effect), whereas in cases where the inner air temperature is lower than the outside air temperature, the reverse occurs (the reversechimney effect). Generally the chimney effect occurs in winter and the reverse-chimney effect occurs in summer because the inner temperature is equal to the MAST. Airflow velocity is proportional to the altitude difference between lower and upper entrances. The cave entrance need not be large (i.e. Spötl et al. 2005) and many caves connect to the surface via voids that are too small for access by speleologists.

In addition, a seasonal classification based on airflow direction fluctuation is used. The year is usually divided into four airflow seasons based on the diurnal variation of cave airflow. Cave airflow direction depends mainly on the difference in air temperatures inside and outside the cave (Moore \& Sullivan 1978; Hasegawa et al. 2014; Peyraube et al. 2017).

Hasegawa et al. (2014) employed the following classification to the observed temperature variations of a cave in northern Japan, spring (Sp) was correlated to a period from late March to early June, summer (Sm) from late May to mid-October, autumn (A) from late September to early December, and winter (W) from early November to early April. Airflow direction is assumed to follow the seasonal fluctuation of outside temperature whereas inside temperature is assumed to be constant. The seasonal fluctuation of airflow direction is also similar to that reported in previous studies (Buecher 1999; Spötl et al. 2005).

The study of the microclimate of caves is a topic that is regaining relevance due to the study of cave flora and fauna, thermodynamic conditions for karst processes underground and hydro-geologic features of speleothems (Luetscher et al. 2008; Ravbar \& Kosutnik 2014; Faimon et al. 2012). Emphasis is given to the study of caves to estimate human impact when caves are visited. Fernández-Cortés et al. (2006) investigate the effects of human presence inside the geode, the increase of the water vapour content and temperature of the air, turning the crystal into a surface capable of condensation. Badino et al. (2011) studied the impact of air circulation on the giant gypsum crystals, and the development of new crystal phases. Current studies focus on conservation problems in time and space. In these approaches, knowledge of the underground environment is linked to monitoring climatic parameters and to the impact of the anthropogenic activity. Within the same objective, study of French Lascaux Cave focused to simulate the evolution of changes in the levels of temperature and humidity both in the air and in the rock (Lacanette et al. 2009, 2013; Malaurent et al. 2006).

Thus, we can see that micrometeorological factors are more than simply of academic interest. They can play an important role in development of best practices in cave resource management issues.

Petites Dales cave, a single entrance cave in Normandy (north west of France), is an "underground laboratory" in which it is possible to study the cave aerology easily. In this study, we investigate how Petites Dales cave ventilates. The objectives are to : (i) describe the behaviour of the cave as an air trap and verify how the cave is linked to external environment; and (ii) examine the effects of interactions between cave and external environment on cave air circulation and (iii) analysis the annual airflow regime and its impact on the cave air temperature. The article specifically focuses on air circulation at the entrance of the cave. The exchange of air with the surface atmosphere (cave ventilation) directly affects temperature, humidity and cave air dynamics. Variation of air composition is considered as a result of a mix between external and internal air which resulted from displacement of air mass.

Seasonal (warm and cold season), intra-seasonal and diurnal (day and night) trends of Petites Dales Cave were assessed. In order to describe the natural ventilation of this cave, a thorough high frequency monitoring and analysis of air temperature, weight of water vapour in air and airflow were conducted. Sampling regime was done from April 2014 to June 2015. Temperature was measured with in situ probes inside the cave, at the exterior in the area near the only entrance of the cave. Measurements of airflow at and near the entrance of the cave are performed through sampling campaigns at specifically chosen times of the year (Lecoq et al. 2014; Magne et al. 2015).

\section{METHODS}

\section{SITE DESCRIPTION}

The study was performed in the Petites Dales (PD; Fig. 1) cave in the Channel French coast. The PD cave is an im- portant chalk cavity in the Western Paris Basin because of its dimensions. The chalky limestone strata of the Normandy plateaux present a large variety of facies but the 


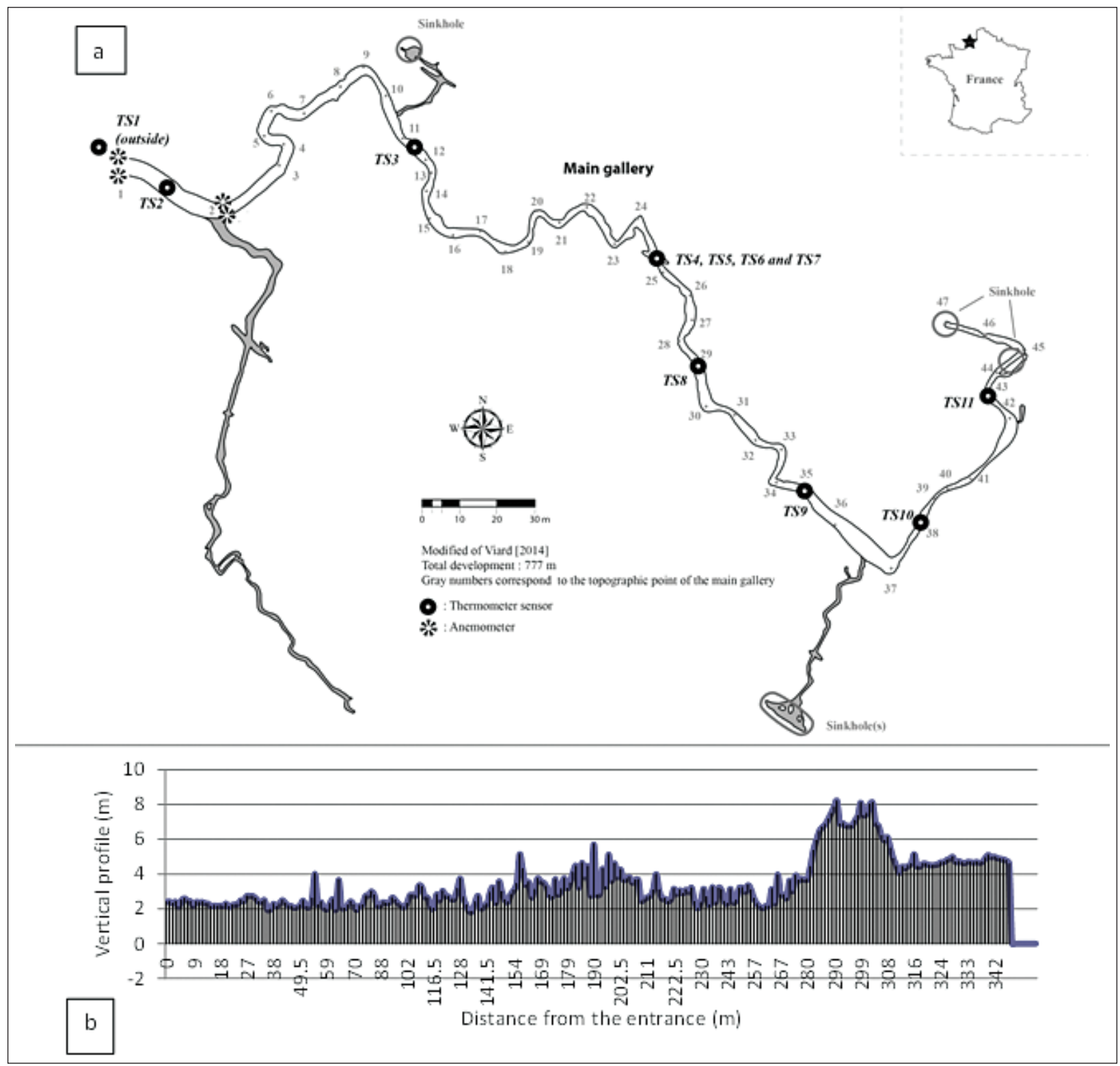

Fig. 1: (a) The Petites Dales cave position and sketch map of the monitoring site and (b) height of the ceiling along the main gal lery.

hydrological characteristics are very similar to one another because of the major role played by the porosity in the karst. The low regional elevation (less than $300 \mathrm{~m}$ a.s.l.) and the lack of main tectonic features (with the exception of the eroded Bray anticlinal) limit this geomorphological expression beneath continuous weathering covering of several metres deep. This is sometimes reinforced by elements of pre-existing Tertiary strata that conceal the chalk beneath. In this entire region, chalk is only visible in the sea cliffs of the English Channel, northwest of the region, and in the deep valley of the River Seine that cuts through Eastern Normandy, from SE to NW. These natural geological sections reveal a large number of karst phenomena, more specifically fossil entrances and springs.
The input karst landforms (potholes, pipes, sinkholes, etc.) develop under the weathering cover and constitute the active front (cryptokarst) but they are not normally being visible.

The PD cave, $1.3 \mathrm{~km}$ from the sea shoreline, is a major fossil cave in Upper Normandy. Its $800 \mathrm{~m}$ of galleries represent specifically a large collector, which was completely infilled before it was opened by cavers (Rodet \& Viard 2009). Its conduit size, the absence of stepping in the galleries, and the absence of a conduit confluence or diffluence in the upper part of the collector, and the absence of a by-pass gallery illustrating a destabilisation or a significant migration of the drainage axis, and the important elevation of the per ascensum digging; together 
these features, all elements of terrestrial evolution, indicate a long stable period of water level and of the drainage conditions. Despite the proximity of this cave to the coastline border it was never influenced by littoral processes. It seems that drainage conditions were only modified by the Petites Dalles valley incision that allowed the water to flood away from the aquifer. This valley incision was only deepened as the coastline approached. Therefore it seems that the cave drainage was fossilised by the dale incising under the karst network base.

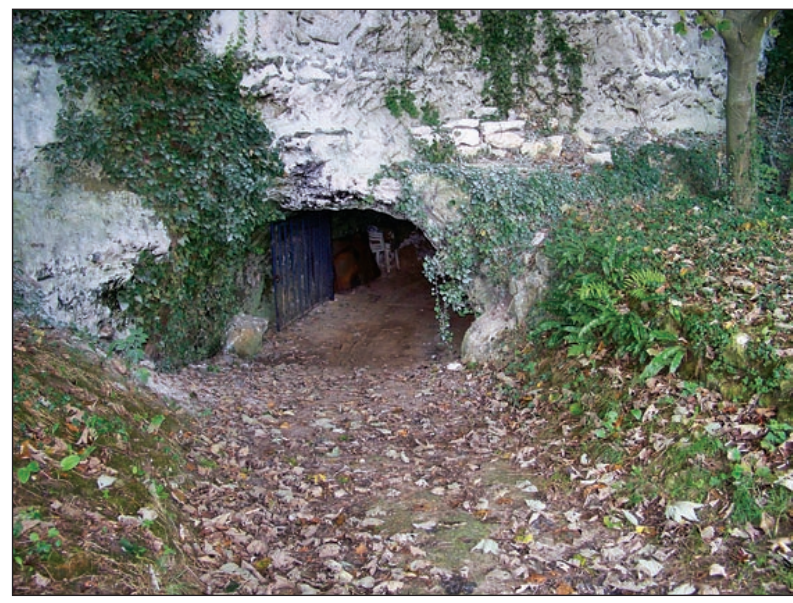

Fig. 2: Photography of the entrance of the Petites Dales Caves (Photo: R. Hardt).

The cave consists of one entrance main gallery; this gallery is from 2 to $5 \mathrm{~m}$ wide, $10 \mathrm{~m}$ high in its largest section. The length of the main gallery is $450 \mathrm{~m}$ (Rodet et al. $2006,2009,2013)$. At $30 \mathrm{~m}$ of the entrance, a first conduit "Siphon gallery" is connected to the main gallery, this one is not connected to the surface and goes down from $7 \mathrm{~m}$ immediately.

The cave is almost horizontal with an elevation of $27.5 \mathrm{~m}$ above sea level. Rock thickness above the cave varies from 20 to $45 \mathrm{~m}$ according to the elevation of the surface.

The climate is temperate with a mean annual temperature of $11^{\circ} \mathrm{C}$, a mean summer temperature between 18 and $20^{\circ} \mathrm{C}$, and a mean winter temperature between 3 and $7{ }^{\circ} \mathrm{C}$, the mean annual precipitation is around 800 mm (Météo-France, 2017).

\section{MONITORING}

Several cave monitoring sites inside and outside PD were equipped with data loggers or visited with different time intervals. Long-term data were collected from April 2014 to June 2016. Cave air temperatures were measured with sensors distributed along the cavity but only records from the outside temperature logger and records from the logger at the topographic station 2 were used in this study (respectively points TS1 and TS2 denoted on the Fig. 1 (a)). The topographic station 2 is located at $25 \mathrm{~m}$ from the entrance. Air temperatures were recorded at $30 \mathrm{~min}$ intervals) and logged externally (accuracy $\pm 0.1^{\circ} \mathrm{C}$ ).

The topographic stations 1 and 2 (numbered TS1 and TS2 on the Fig. 1(a)) were visited approximately once a month and additional air temperature, moisture balance and relative humidity were recorded with portable apparatus Kimo HD 200 (certified). At the same time wall temperature was measured at each location using an IR thermometer Fluke 568 IR with an accuracy of $1 \%$.

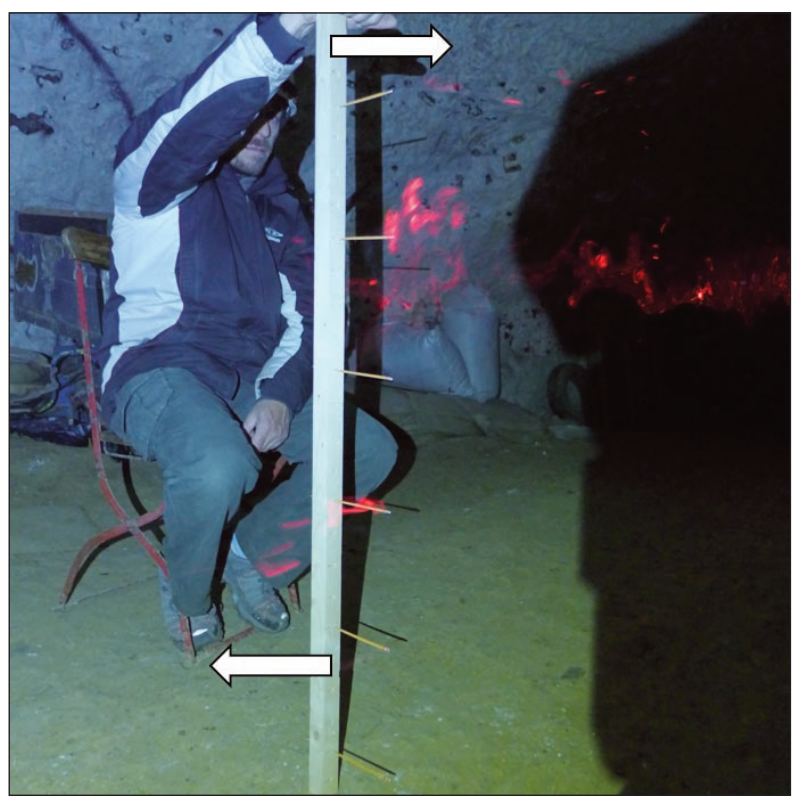

Fig. 3: In situ visualisation of airflow using a laser sheet. The smoke into the red plane of light is clearly visible. Arrows indicate the opposite directions of flows (Photo: L. Magne).

To relate daily and seasonal microclimatic parameters monitored in Petites Dales cave to external conditions, we used daily temperature, barometric, psychrometric data from the nearby Dieppe meteorological station. This meteorological station is located at $30 \mathrm{~km}$ north-east from the cave and at a comparable elevation (27.5 $\mathrm{m}$ for the cave, $32 \mathrm{~m}$ for Dieppe). Data from Dieppe, recorded 1 hour intervals between 2013 and 2015, are used for validation of the data from the data logger located outside to the cave.

To better understand the karst underground climate, and especially its response to the external climate, additional data were recorded for short periods. Airflow and temperatures were measured three times for short periods (September 21-23, 2014; October 26-28, 2015; January 31,2015$)$ by digital hot-wire anemometers Thermo-anemometers HD2103.1 (measurement range: speed from 0 to $40 \mathrm{~m} / \mathrm{s}$, temperature range from $-30{ }^{\circ} \mathrm{C}$ 
to $80{ }^{\circ} \mathrm{C}$, measurement resolution: speed $0.01 \mathrm{~m} / \mathrm{s}$, temperature sensitivity $0.1^{\circ} \mathrm{C}$; measurement accuracy: speed $\pm 0.01 \mathrm{~m} / \mathrm{s}$, temperature $\pm 0.1{ }^{\circ} \mathrm{C}$ ). During the daytime monitoring in September and October, outside air temperature varied from $9{ }^{\circ} \mathrm{C}$ to $25^{\circ} \mathrm{C}$ due to diurnal variation. Airflow and temperature were observed inside the cave at TS2 (Fig. 1) in September and October at veryhigh frequency (5 seconds interval). The two thermoanemometers were respectively placed at $20 \mathrm{~cm}$ from the floor and the ceiling.

On 22, 23 September 2014 and 31 January, 2015, the velocity profiles of air were measured directly at the entrance of the cave and at the topographic station number 2 (Fig. 1) at very-high frequency (1 second interval) along the full height of the cave over a 10 minutes period. Airflow and temperature fluctuate slightly due to turbulence, so the average and RMSE (root-mean-square error) values are calculated.

When investigating a complicated and unknown flow, the first step is often a flow visualization experiment. The ability to see what is happening is indispensable to understanding the processes involved. The classical set of flow visualization experiments involved the laser light sheet technique. The beam from a $\mathrm{He}-\mathrm{Ne}$ laser was passed through a cylindrical lens and split into a plane or sheet of light. The light sheet then passed through the test section illuminating a cross section of the flow. The flow field was made visible by the introduction of smoke which is entrained into the vortices. The light sheet could be oriented either perpendicular to or parallel to the floor. The flow was then photographed or filmed and analysed later.

\section{RESULTS AND DISCUSSION}

\section{ANNUAL VARIATIONS OF AIR TEMPERATURES}

Observed meteorology at the Petites Dales site over the studied period is consistent with local long-term archives from Dieppe, displaying typical seasonal weather patterns of north France (hot in summer, periodic cold fronts October to March). Seasonal variation of average air temperature and diurnal variation of air temperature from Dieppe and outside the cave are both shown on the Fig. 4 (a). The curves are superimposed, which means that the general trends of temperature are visible on both curves, but the amplitudes may change due to different solar light intensities on both sites. Air temperature inside the cave on the Fig. 4 (a) shows the same trends, that is seasonal variation of average air temperature and diurnal variation.

Temperature outside the cave averaged $13{ }^{\circ} \mathrm{C}$ from April, 2014 to May, 2015 with a standard deviation of $5.3{ }^{\circ} \mathrm{C}$, while temperature inside the cave averaged $11.0^{\circ} \mathrm{C}$ far from the entrance which corresponds to the mean annual temperature of this area.

From May 2014 to June 2014, an enlargement (Fig. 4 (b, c) with double axis) exhibits daily variation of temperature both outside and inside of the cave at TS2 but with a lag between both. Inside temperature variations show a small delay of approximately one hour with respect to the outside temperature. This lag is not constant with seasons. Cave meteorology lags and dampens variations in local outside atmosphere temperature suggesting local weather drives cave entrance meteorology.

\section{AIRFLOW RESULTS AND DAILY INVERSION}

Fig. 5 (a) presents the variations of temperature and airflow measured with hot-wire anemometers located at TS2 (see Fig. 1) at the floor and ceiling of the cavity. Figs. $6(\mathrm{a}, \mathrm{b}, \mathrm{c})$ show the airflow profiles measured at the entrance along a vertical line at equal distance from lateral walls of the cavity. The starting hours of measurement is indicated on the graphs. It should be noted that the drawn values are an average over 10 minutes of measurement to avoid turbulence. It is assumed that during the measurement, the airflow doesn't change in a significant way. To ensure this hypothesis, at the end of the measurement along the vertical line, a second one is realised at the points where the velocity was the higher.

During this period, from September 21, 2014, 17:45 to September 23,2014, 21:30, the following thermal and kinetic characteristics of the air can be deduced.

For the temperatures, it is observed that on Fig. 5:

- The top temperature (red curve) recorded by thermometer close to the ceiling fluctuates in connection with the external temperature; the temperature follows diurnal cycle with a lag of around 2 hours. In a first period (night time), it decreases and reaches a minimum value close to the mean temperature of the cave far from the entrance at this period of the year $\left(11.6^{\circ} \mathrm{C}\right)$ at the end of the night. Then, after a stagnant time greater than two hours, the temperature increases and follows the outside temperature with some delay.

- The bottom temperature (light blue curve) recorded by thermometer close to the floor remains constant 

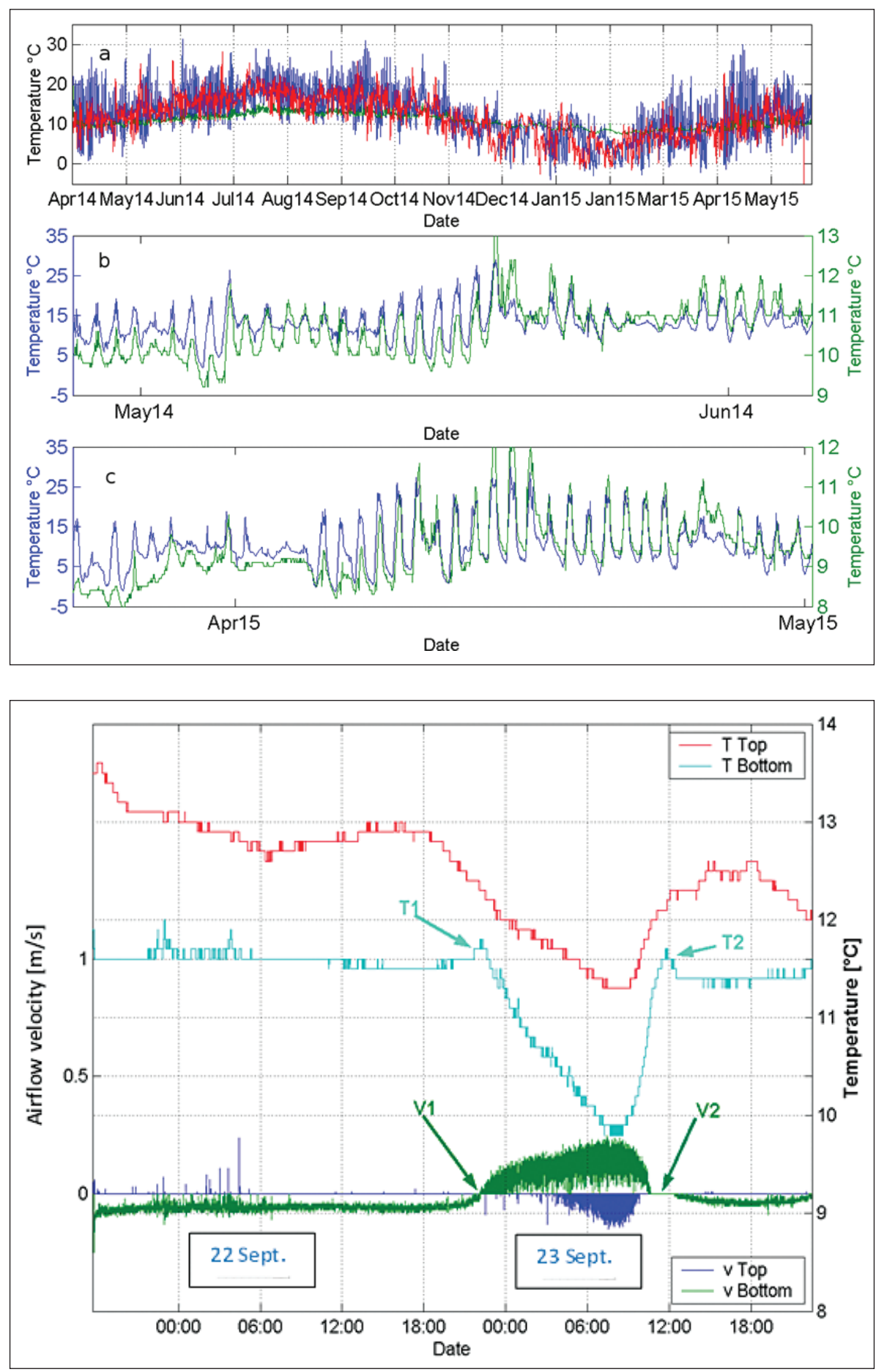

Fig. 4: (a) Dieppe, outside and inside Petites-Dales cave temperatures from April 2014 to May 2015; blue: outside temperature; green: inside temperature, red: Dieppe meteorological station temperature. (b) and (c): enlargements of the previous graph showing temperature records from May 2014 to June 2014 (middle), and from April 2015 to May 2015 (bottom). The left (blue) and right (green) axis correspond respectively to outside and inside temperature scale (The amplitudes of both $y$-axes are conserved for the two last graphs).
Fig. 5: Airflow velocity (left axis) and temperature (right axis) at the TS2 measured in September (starting time: 21 September at 17:45). On the experimental results are superimposed arrows to emphasize important behaviours (see text for details). The time scale starts at the beginning of data acquisition with the two anemometers (see paragraph monitoring for a description of the measurements). (mean temperature of the cave far from the entrance at this period of the year, that is $11.6^{\circ} \mathrm{C}$ ) until the point $\mathrm{T}_{1}$ where a peak is observed; this peak is higher than the experimental uncertainties. Then, the temperature decreases at values lower than the mean temperature of the cave. On September 23, at roughly 7 a.m., the temperature reaches the minimal value. After a stagnant time greater than one hour, the temperature increases and reaches a maximum at $T_{2}$ when a second peak is visible. It then decreases back to the average temperature of the cave.

Dealing with the velocities measured with the two hot-wire anemometers, we adopt the following convections: positive velocity means direction of air from outside to inside, and conversely negative velocity indicates motion of air from inside to outside; the following remarks can be made: 


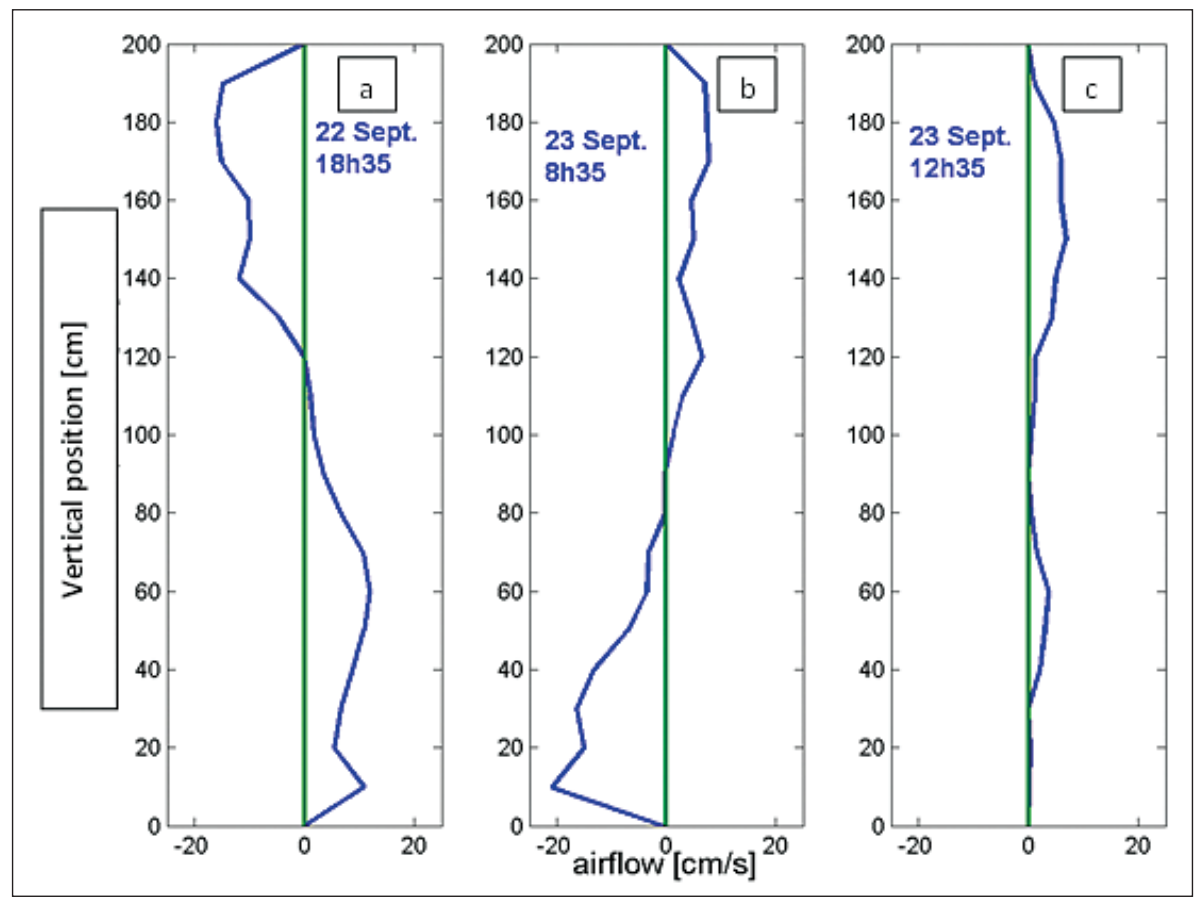

Fig. 6 (a), (b), (c): airflow profiles measured at the entrance of the cave with the hot-wire anemometers and incense tip at different times. At each vertical positions (every 10 centimetres), an average over 10 minutes of measurement is made to avoid turbulence. The times indicated mean the beginning of the measurement. The vertical lines (green) show the zero velocity.

- Before the point $\mathrm{V}_{1}$, and after $\mathrm{V}_{2}$, the top velocity (dark blue) is close to zero; negative value of bottom velocity (green) indicates that airflow at the bottom moves from inside to outside of the cavity.

- From the points $\mathrm{V}_{1}$ to $\mathrm{V}_{2}$, the direction of bottom velocity changes (change of sign), bottom airflow comes from outside to inside and the top airflow moves toward outside.

It should be noticed that, at the time corresponding to the points $\left(\mathrm{T}_{1}, \mathrm{~V}_{1}\right)$ and $\left(\mathrm{T}_{2}, \mathrm{~V}_{2}\right)$, the velocities are equal to zero and at the same time bottom temperature profile presents these two peaks. No significant changes on the slope of the top temperature are observed. These two peaks $\mathrm{T}_{1}$ and $\mathrm{T}_{2}$ may be attributed to stagnant air inside the cave and a mixing of top and bottom air.

The airflow velocity was measured along a vertical line at equidistance from lateral walls at the entrance of the cave that is far from TS2 $(35 \mathrm{~m})$ to avoid any perturbations on the previous measurements (Fig. 5). The airflow velocity presents an S-shaped profile for the horizontal velocity component as shown in Fig. 6 (a, b). In the mid-depth region, the fluid is practically stagnant. These inflow and outflow are clearly visible in Fig. 3 on which arrows indicate the two-opposite directions of airflow.

On 11 January 1970 at 8:00 p.m., McLean (1971) already observed inflow and outflow components at the Natural Entrance of Carlsbad Cavern (McLean 1971; Hill 1987). But, if a cave has a single entrance, it may be difficult for the outside air to enter into the cave simply due to high outside barometric pressure, unless compressibility and transient flow are accounted for.

In Fig. 6 (a), we can see that a large inflow component is measured in the upper part of the entrance, and a smaller outflow component in the lower part on 22 September at 6:35 p.m.. The plot seems to describe well the ventilation conditions at this period of time. In Fig. 6 (b) on 23 September at 8:35 a.m., the airflow components are in the opposite direction as previously, that is an outflow component is measured in the upper part of the entrance and an inflow component in the lower part. These flows are lower in intensity than the one measured 12 hours before Fig. 6 (a).

Finally, in Fig. 6 (c), the airflow is close to zero, that is the air is in a stationary state. In Fig. 6 (c), the airflow velocity close to zero indicates that we are at an inversion time and this measurement corresponds to the point (T2,V2) of Fig. 5. Unfortunately, we didn't catch the point (T1, V1), but this one seems to be shorter in time than the other characteristic point (T2, V2).

From these observations, we can conclude that between end of September 22, 2014 to beginning of September 23, 2014 the direction of airflow changes twice, that is daily airflow inversions are clearly observed. To our knowledge, this measurement effort is the first attempt to capture the dynamical behaviour of such cave micrometeorological systems.

\section{RAYLEIGH NUMBER AND FREE CONVECTION}

Temperature differences between the top and bottom walls of the component air $\left(\Delta \mathrm{T}_{\mathrm{a}}\right)$ are determined by many factors and, thus, are unknown. Wilson (unpublished 


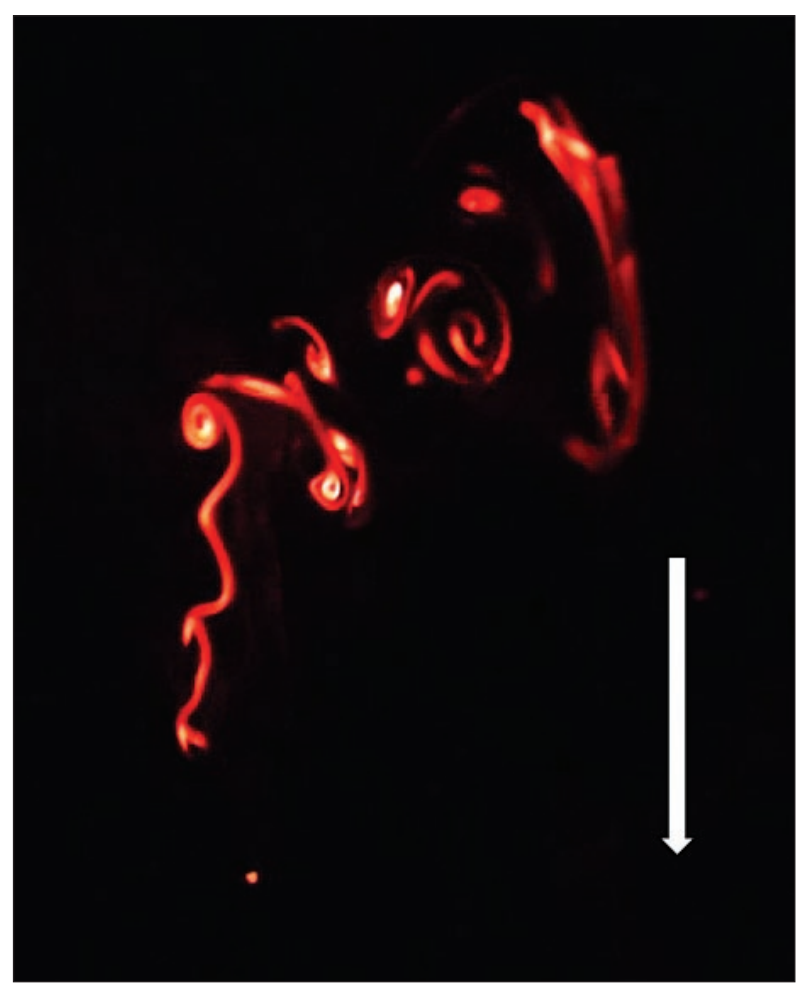

Fig. 7: 2D von Kármán vortex street observed at the site number 2 visualised on 23 September, at 1 a.m.; the vertical arrow indicates the direction of gravity; the entrance of the cavity is on the right of the figure (Photo: L. Magne).

note, 2004) has proposed replacement of this unknown difference by what we do know, but which still represents the thermal-buoyancy forcing, that is, the Rayleigh number $R a$.

The Rayleigh number $R a$ is based on the ratio of thermally-induced buoyancy forces (which drive convective fluid flow) to the viscous forces inhibiting fluid movements:

$R a=\frac{g \beta\left(T_{\text {top }}-T_{\text {bottom }}\right) \rho^{2} C_{p} D_{h}^{3}}{\mu k}$

where $g$ is the gravitational acceleration $\left[\mathrm{m}^{2} / \mathrm{s}\right], \beta$ the volumetric expansion coefficient for temperature $[1 / K]$, $\rho$ the density of air $\left[\mathrm{kg} / \mathrm{m}^{3}\right], c_{\text {p }}$ the specific heat capacity at constant pressure $\left[J . \mathrm{kg}^{-1} \mathrm{~K}^{-1}\right], D_{h}$ the hydraulic diameter $[m], \mu$ the dynamic viscosity of air $\left[N . s . m^{-2}\right]$ and $k$ the thermal conductivity of air $\left[W \cdot m^{-1} \cdot K^{-1}\right]$.

Buoyancy can easily lead fluid to enter or exit a single cave entrance (Shindo 2005). This phenomenon can be linked to a kind of Rayleigh-Bénard instability (Bergé \& Dubois 1984; Shindo 2005). Rapidly rotating convection is common in stars and planets, and is present in the Earth's oceans and liquid metal core (Julien et al. 2012). In laboratory observation, Rayleigh-Bénard convection is the buoyancy-driven motion of a fluid contained be- tween two horizontal plates and heated from below. A dimensionless control parameter specifies the system, the Rayleigh number $R a$. It provides a dimensionless measure of the thermal forcing, and a critical Rayleigh number $R a_{c}$ indicates when this instability will occur (Talukdar et al. 2008).

The density difference between the air-water vapour mixture at the bottom and top of the cave duct and in the bulk air stream results in natural convection, which is quantified in the same way by the Rayleigh number. The air has the following properties (assuming constant properties with variations of water concentration) $\mu=0,0815$ N.s. $\mathrm{m}^{-2} ; \rho=857 \mathrm{~kg} / \mathrm{m}^{3}, c_{p}=1880 \mathrm{~J} . \mathrm{kg}^{-1} \mathrm{~K}^{-1}, \mathrm{k}=$ $0.0263 \mathrm{~W} \cdot \mathrm{m}^{-1} \cdot \mathrm{K}^{-1}, \beta=0.0035 \mathrm{~K}^{-1}$, and the hydraulic diameter $D_{h}=1,8 \mathrm{~m}$ (Lacanette et al. 2009). The Rayleigh number at the entrance of the cavity is estimated to $R a \approx 4105$.

The critical Rayleigh number measured by Behringer \& Ahlers (1982) for helium and by Koschmieder \& Pallas (1974) for silicone oil was found to be only a function of the boundary conditions. The critical Rayleigh number for moist air is around $R a_{c}=1708$ (Lir \& Lin 2001; Furbish 1997).

Once the $R a$ number exceeds the critical value $R a_{c}$, the dominant energy transport mechanism in the fluid would be convection (Rayleigh 1882, 1916).

The estimate of the Rayleigh number may provide an indication of "potential inversions". We call them "potential" because the Rayleigh number must be larger than the critical value, and it requires a long time (around one hour) to trigger.

Fig. 7 is a visualisation of the 2D von Kármán vortex street as known from literature (Mass et al. 2003). The red dot is the incense tip used to produce smoke into the laser sheet. 2D von Kármán vortex street indicates that the airflow is coming from the floor and goes to the ceiling. A convection loop takes place at the TS2, $31 \mathrm{~m}$ from the entrance. The outside airflow then comes close to the floor, the inside airflow follows the ceiling, and part of the two airflows mix at this point of observation. Contrary to the explanations of Peyraube et al. (2017), the airflow is not only confined into the entrance, but flows far into the cave.

\section{DRIVING FORCE OF THE AIRFLOW INVERSION}

A large consensus exists stating that driving forces of airflow are proportional to the differences in air densities (Cigna 2002; De Freitas et al. 1982; Spötl et al. 2005; Faimon et al. 2012; Faimon \& Lang 2013; Borsato et al. 2015).

Airflow depends on density difference in a non-linear way, which is consistent with theoretical assumptions 

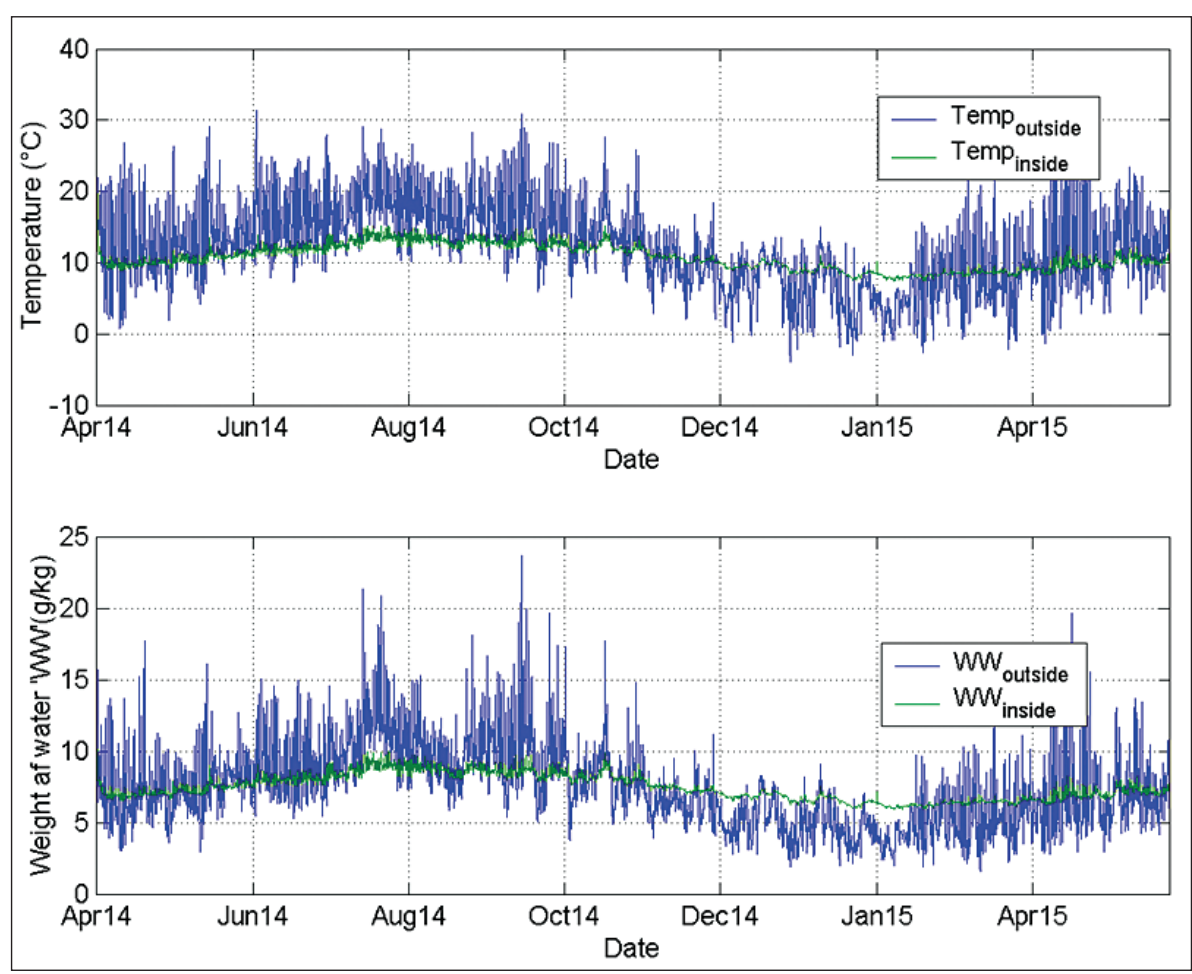

Fig. 8: (a) Temperatures outside (blue) and inside at the entrance (green) the cavity. (b) Weight of water vapour in air ("WW") coming from outside (blue) and inside (green).
(Lismonde 2002). A rough estimate shows that the velocity difference depends on the square root of the density difference, which is similar to a chimney effect. This result is consistent with the fact that the air is stratified into the same horizontal part of the pipe. The second important point is that zero airflow is not associated necessarily with zero density difference, but as it is explained above, the Rayleigh-Bénard convection requires time to destabilize the fluid layers and airflow to warm up.

Under the previous hypothesis and this existing consensus, is it interesting to represent the temperature inside and outside the cavity in correlation with the weight of water in the outside and inside air.

The volumetric mass of humid air may be calculated as a mixture of ideal gases. In this case, the partial pressure of water vapour is known as the vapour pressure. Using this method, error in the density calculation is less than $0.2 \%$ in the range of $-10^{\circ} \mathrm{C}$ to $50{ }^{\circ} \mathrm{C}$. The volumetric mass of humid air (ha) is found by:

$\rho_{h a}=\frac{p_{d}}{R_{d} T}+\frac{p_{v}}{R_{v} T}=\frac{p_{d} M_{d}+p_{v} M_{v}}{R T}$

where $\rho_{h \alpha}$ is the volumetric mass of the humid air $\left[\mathrm{kg} \cdot \mathrm{m}^{-3}\right], p_{d}$ the partial pressure of dry air $[\mathrm{Pa}], R_{d}$ the specific gas constant for dry air [287.058 J/(kg.K)], $T$ the temperature $[\mathrm{K}], R_{v}$ the specific gas constant for water vapor $[461.495 \mathrm{~J} /(\mathrm{kg} . \mathrm{K})], M_{d}$ the molar mass of dry air $[0.028964 \mathrm{~kg} / \mathrm{mol}], M_{v}$ the molar mass of water vapour, [0.018016 kg/mol], $R$ universal gas constant $[8.314 \mathrm{~J} /(\mathrm{K} . \mathrm{mol})]$.
The vapour pressure of vapour may be calculated from the saturation vapour pressure and relative humidity. It is found by $p_{v}=\Phi p_{\text {sat }}$ with $\Phi$ the relative humidity and $p_{\text {sat }}$ the saturation vapour pressure $[\mathrm{Pa}]$.

Following Picard et al. (2008), the vapour pressure at saturation is given by:

$p_{\text {sat }}=1 \times \exp \left(A T^{2}+B T+C+D / T\right)$

with $\mathrm{A}=1,2378847 \times 10^{-5}\left[\mathrm{~K}^{-2}\right], \mathrm{B}=-1,9121316 \times 10^{-2}\left[\mathrm{~K}^{-1}\right]$, $\mathrm{C}=33,93711047[-]$ and $\mathrm{D}=-6,3431645 \times 10^{-3}[\mathrm{~K}]$.

These formulations can be combined into the weight of water vapour in air $\left[\mathrm{g} \cdot \mathrm{kg}^{-1}\right]$ :

$W_{\text {water }}=\frac{-0,622 p_{v}}{p_{v}-p}$

with $p$ the total pressure of gas mixture $[\mathrm{Pa}]$.

The volumetric mass of both external and cave air is calculated according to the previous equation equations. The atmospheric pressure (total pressure of gas mixture) is taken from Dieppe meteorological station and corrected to the relevant altitude. The relative humidity of external air is taken from the same meteorological station. The relative humidity of internal air is assumed not to vary significantly in the short period between two successive measurements.

Figs. 8 show respectively the inside and outside temperatures and weight of water vapour in air 'WW' coming from outside and inside air. There is a clear dependence of the weight of water vapour in air (WW) to the temperature, but it is not obvious from these graphs 
when the air of the cave is going out from the ceiling or from the floor as it was observed and presented in Fig. 5. Nevertheless, two main periods can be determined roughly:

- from mid-June to beginning of October 2014, WW inside the cave is lower than from outside, the air coming from outside may enter the cavity from the ceiling;

- conversely, from November 2014 to March 2015, the air from the cave moves outside from the ceiling and the average velocity and temperature profiles are similar to that shown on Fig. 5.

- for the other periods, at this point of the analysis, we cannot conclude if the outside fluid flow enters from the ceiling or the floor of the cavity.

To overcome this difficulty, the half-hourly logging observation data of September, 2014 are presented in details in Fig. 8 using the Rayleigh criterion defined previously.

Fig. 9 is interesting because the data around September 23, 2014 may be correlated to the results presented above in Fig. 5. The driving force of the airflow inversion is the difference in weight of water vapour in air (WW) which stratifies air, but the buoyancy-driven motion triggers when the Rayleigh number is sufficiently higher than $\mathrm{Ra}_{\mathrm{c}}$ for a long time (estimated to more than one hour). Fig. 9 (d) shows precisely when the Rayleigh number is larger than the critical ones, so that when inversions can occur. The weight of water vapour plays a crucial role on the inversion process. It is presented in Fig. 10 in details.

Fig. 10 presents measurements realised in 04 December 2015; the weight of water vapour at the entrance of the cave stays constant with respect to the time, at a value close to 7.6. The outcoming air has a weight of water vapour equal to 6.2. Outcoming air temperature falls under the temperature of the cave, but in that case, no inversion was measured. The colder air is not the denser one, so that the inversion process doesn't take place.

\section{ANNUAL INVERSIONS}

From this analysis, the number of potential inversions every month may be estimated, that is the specific moment when the Rayleigh number is larger than $\mathrm{Ra}_{c}$. They are indicated as red segments on the graphs of Fig. 9 for a small period in September. The same work was made for each month, but not presented here for clarity.

The detection of inversions is made automatically, so that $\mathrm{Ra} \gg \mathrm{Ra}_{\mathrm{c}}$ was the only criterion. Many others authors introduce the virtual temperature (Sánchez-Cañete et al. 2013; Faimon et al. 2012; Vieten et al. 2016) instead of the Rayleigh number to estimate the driving force. The virtual temperature calculation included
$\mathrm{CO}_{2}$ effects which are not measured systematically in the present study. Nevertheless, it is not clear if the $\mathrm{CO}_{2}$ concentration (or $\mathrm{P}_{\mathrm{CO}_{2}}$ ) contributes to the driving force (see the opposite analysis of Vieten et al. (2016) and Peyraube et al. (2017)). A more precise discussion about the $\mathrm{CO}_{2}$ effect in our case is presented at the next subsection.

Dealing with the Rayleigh number, for instance, on September 22 and 23, the criterion is valid for both days, whereas only one inversion was clearly observed on the last date. It should be noted that the Rayleigh number depends only on temperature gradient, with the assumption that density is constant. The second important factor is the necessary time to destabilise the fluid which is larger than one hour. This second point could be understood by the small peak in temperature observed in Fig. 5.

Another non-dimensional number, the density Atwood ratio (Aref 1987; Mueschke et al. 2006) should be introduced; it is usually used in the Rayleigh-Taylor instability. The Rayleigh-Taylor instability occurs when a heavy fluid with volumetric mass $\rho_{1}$ is accelerated towards a lighter fluid with density $\rho_{2}$ and the fluid layers are initially separated by a perturbed interface (Rayleigh 1882; Taylor 1950). For the case considered here, the Rayleigh-Bénard instability is the dominant process in comparison to the Rayleigh-Taylor instability.

Taking into account the difference in weight of water vapour in air and the Rayleigh number satisfying $\mathrm{Ra} \gg \mathrm{Ra}_{\mathrm{c}}$, we can estimate the number of inversions equal to 9 during the month of September. The main incoming flow is on the ceiling of the cave, and when an inversion occurs, the incoming flow falls to the floor for several hours. When the sign of the difference in weight of water vapour changes, from negative to positive sign, the incoming flow rises to the ceiling and is maintained for one or several days.

For November 2014, the inside WW and density are often higher than the outside values. Airflow enters mainly from the floor and the Rayleigh number (calculated based on the difference of temperature) confirms the position of this incoming flow. In that case, we define a «negative» inversion, that is the main incoming flow shift to the ceiling from time to time. The number of inversions $\left(\mathrm{Ra}>>\mathrm{Ra}_{c}\right.$ and long time criterion) is estimated to 6 .

This analysis is conducted for each month and the results are shown on Fig. 12. It is worth noting that two months January and February 2015, are characterized by no inversions. Conversely, it is surprising that in July and August 2014, the number of potential inversions doesn't fall to zero, but it may due to climatic anomalies of this year (colder summer time than usually). 

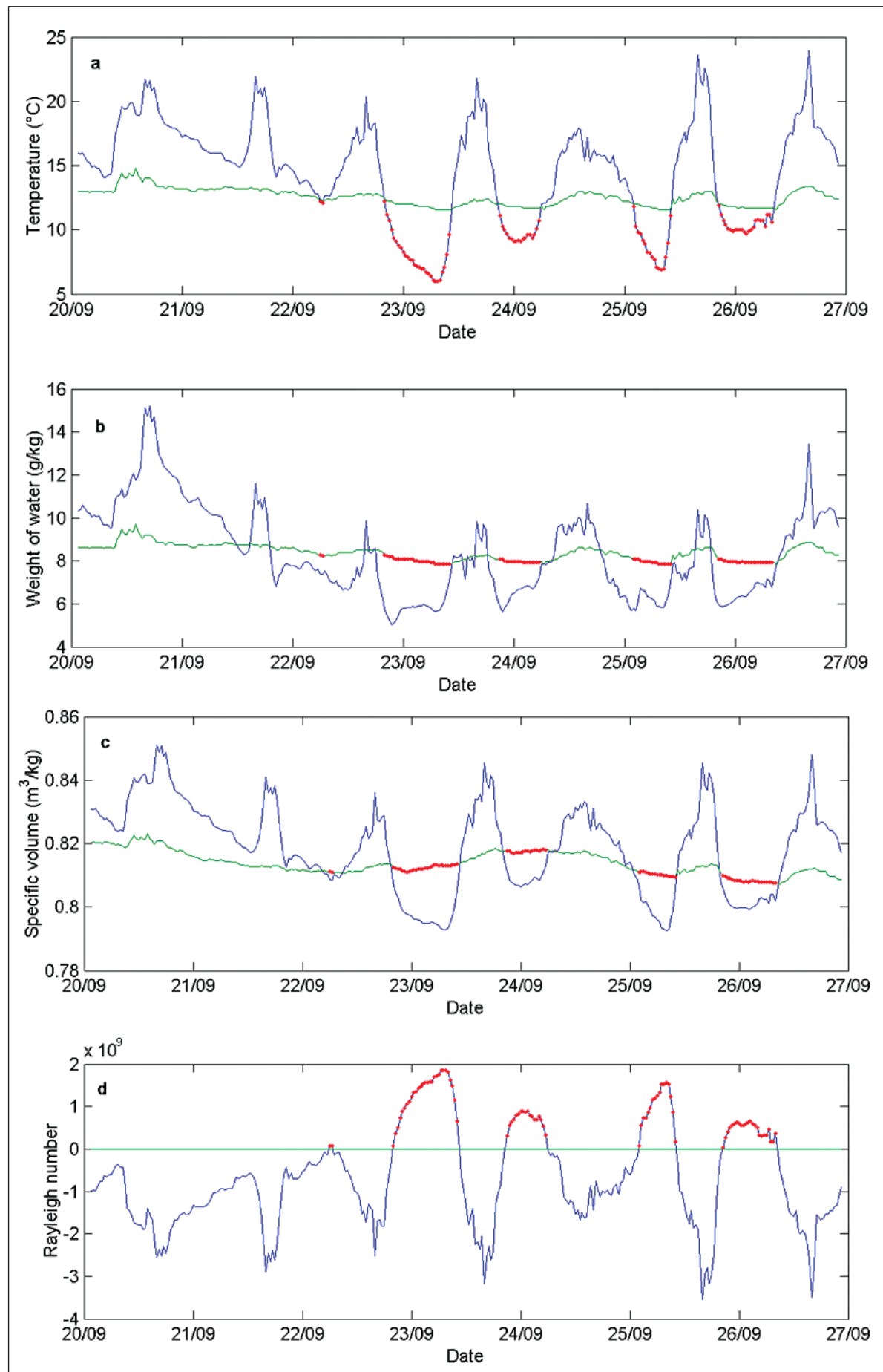

Fig. 9: Data from 20 to 27 September 2014, (a) temperatures inside (green) and outside (blue) the cavity, (b) weight of water vapour in air ' $W W$ ' coming from outside (blue) and inside (green), (c) volumetric mass inside (green) and outside (blue) and (d) Rayleigh number (blue) and the critical value of Rayleigh number $R a=1708$ (green). The red marks on these curves correspond to moments of potential daily inversion (see text for more details).
Basing on the former analysis, we can distinguish the summer ventilation mode during which the inflow enters at the upper part of the cave and a winter ventilation mode at which time the inflow enters at the bottom of the cave.

In September, a distinct shifting was observed from one to the other mode. This shifting is called daily inversion (Fig. 5). Daily inversions were observed in July and August whereas a "summer ventilation mode" is attempted. These schemes are presented on Fig 10, where the mixing of air implies a Rayleigh-Bénard convection process. This process takes place inside the cavity more or less far from the entrance, depending on the weight of water vapour difference between inside and outside air. 


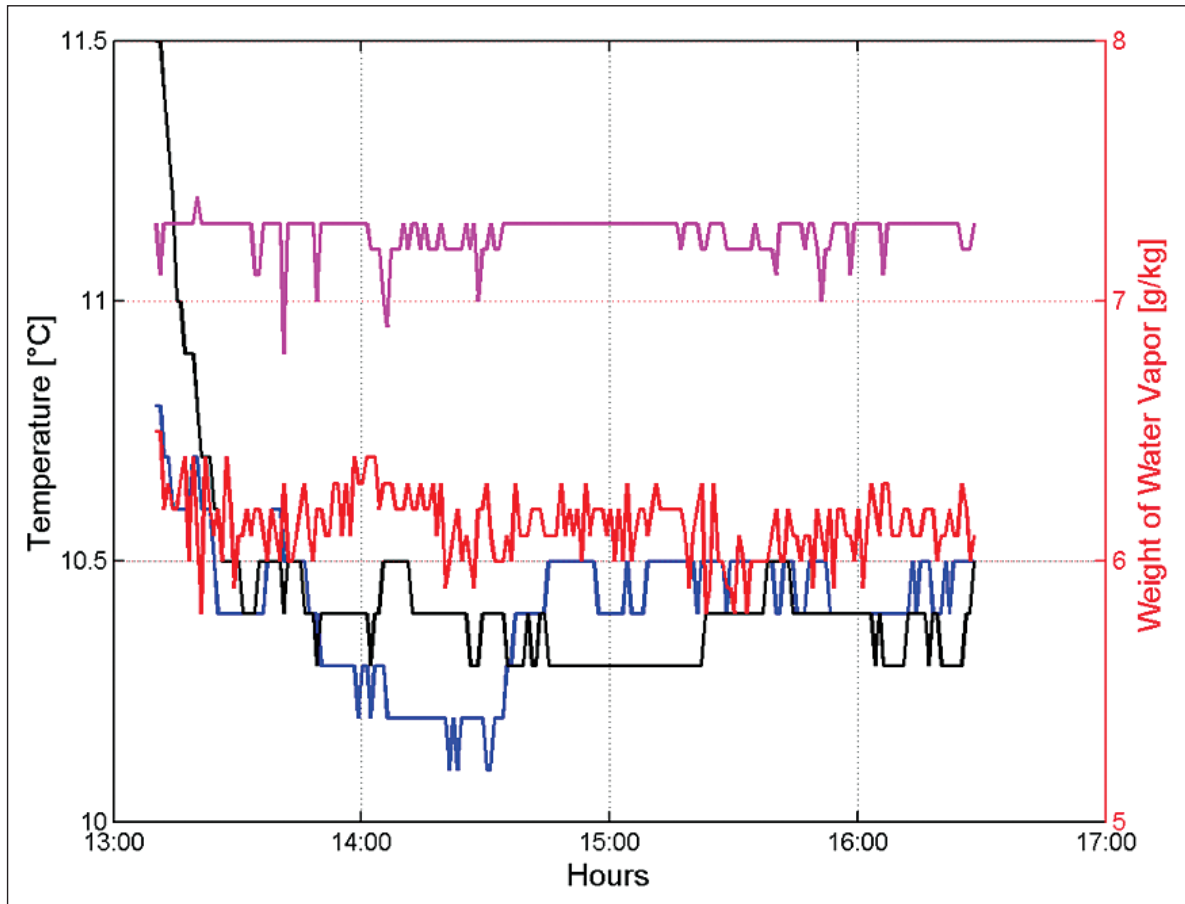

Fig. 10: Specific variations in 04 December 2015 of air parameters in Petites Dales Cave. Shown are: temperature in blue at the ceiling, in black at the floor, weight of water vapour in red at the ceiling, in pink at the floor.

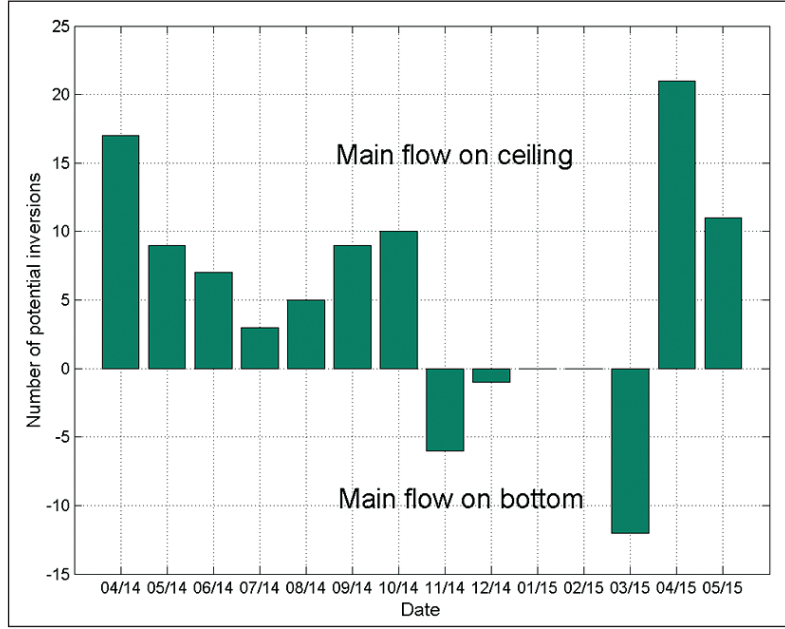

Fig. 11: Monthly potential inversions in the cavity (see text for more details).

\section{CONCEPTUAL MODEL OF THE AIRFLOW REGIME}

The analysis of the air temperature and weight of vapour water measurements gives us also a first impression of the airflow regime inside the cave, which was validated by airflow measurements. Thus we use for the primarily conceptual model these measurements to extrapolate the air movements. The role of $\mathrm{CO}_{2}$ is not included into the conceptual model. Due to the fact that the cave has only one entrance, which is naturally open and not sealed by any door, the distant part of the entrance mainly acts as a cold air trap depending on the external air temperature.
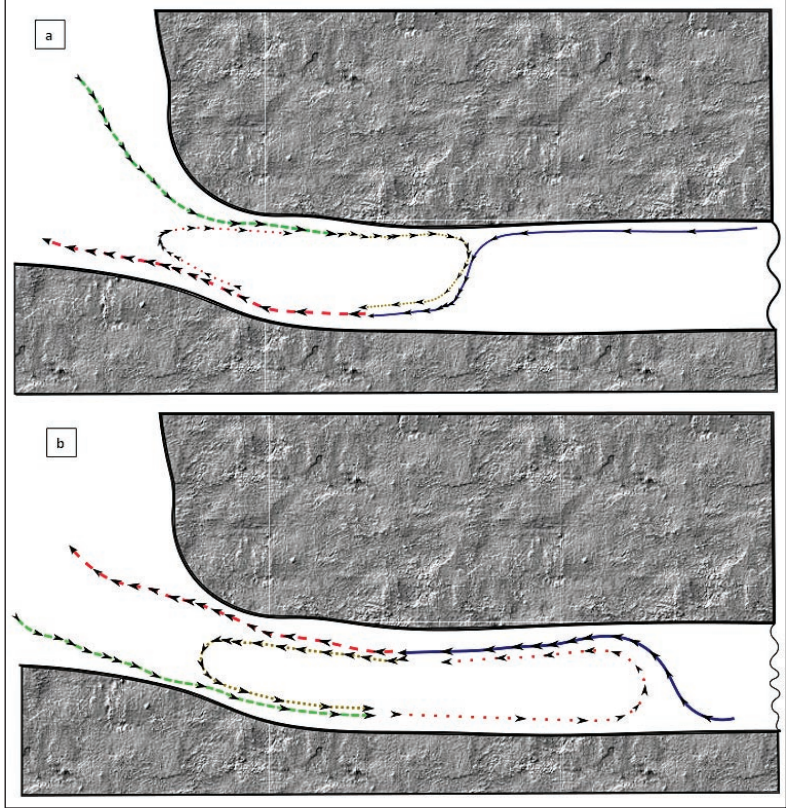

Fig. 12: Schemes of air movements during (a) summer and (b) winter; only the entrance of the cave is represented here, the scale is not representative.

The cave shows three main types of air exchange, a winter situation and a summer situation and the related transition period between the both extremes. These schemes are summarized in Fig. 13.

The winter situation is limited to external temperatures below $11{ }^{\circ} \mathrm{C}$ (the MAST of the cave) causing inflow of dense cold air from outside into the cave 


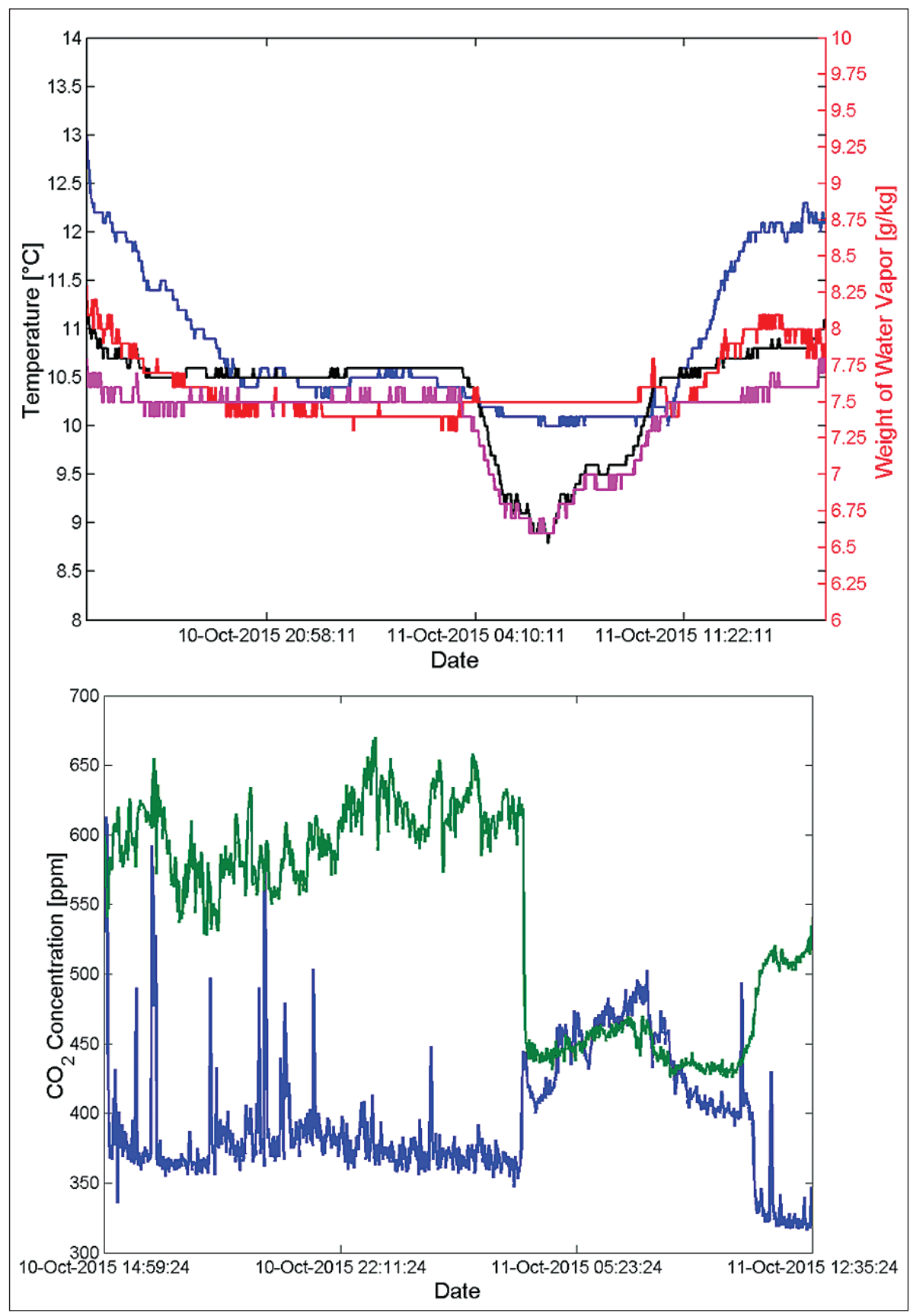

Fig. 13: Specific variations in October 2015 of air parameters in Petites Dales Cave. Shows are: (a) temperature in blue at the ceiling, in black at the floor, weight of water vapour in red at the ceiling, in pink at the floor; (b) $P_{\mathrm{CO}_{2}}$ in green at the floor, in blue at the roof.

caused by specific density differences mainly occurring from November to March. The specific lighter colder air replaces the warm air at the bottom and pushes it out along the ceiling towards the entrance of the cave. Then, convective rolls as presented in Fig. 7 can be observed.

In the transition period in April, when the external air temperature strongly varies around the MAST, the airflow regime is controlled by the changes between winter and summer conditions. The change between night and day is another factor that influences the ther- mal conditions, because nightly dense cold air inflow interrupts the stratification occasionally, but also these short events don't stop the slowly warming of the cave as shown in Fig. 4(a). April is the month where the number of inversions is the more important as shown in Figure With a delay of several weeks, the cave reaches finally the summer static conditions around May. From May to October air exchange between the internal and external air is limited and a distinct inversion develops, which location alternates depending on the daytime and the external weather conditions. 
October the cave remains in the summer condition and slowly transforms again to the transition period, before reaching the winter conditions finally around November.

\section{$\mathrm{CO}_{2}$ AND DRIVING FORCE RELATIONSHIP}

Fig. 13 presents the variations from 10 to 11 October 2015 at the entrance of the cavity. Temperatures, weight of water vapour show clearly an inversion of airflow (inflow falls from the ceiling to the floor) on the 11 October at 4:00 a.m. approximatively. The second inversion (in the reverse direction) occurs on the 11 October at 10:00 a.m.
At the beginning of the inversion, the upper $\mathrm{P}_{\mathrm{CO}_{2}}$ (coming from the cavity) decreases and the lower $\mathrm{P}_{\mathrm{CO}_{2}}$ (coming from outside) increases to reach roughly the same value which correspond to the mean value of the inside and outside $\mathrm{P}_{\mathrm{CO}_{2}}$. At the end of the reverse inversion, $\mathrm{P}_{\mathrm{CO}_{2}}$ reaches the inside and outside values rapidly. As outlined in Fig. 13 (b), it is not clear that the difference in $\mathrm{P}_{\mathrm{CO} 2}$ of the order of $200 \mathrm{ppm}$ contributes significantly to the driving force of the airflow inversion. Further work will have to define the role of the cave in the whole dynamic of $\mathrm{CO}_{2}$ in this karst system.

\section{CONCLUSIONS}

Understanding the relationship between the external climate and the cave environment is a major concern for numerous cave studies, including speleothem based paleoenvironmental reconstructions (Fairchild et al. 2006, 2012), the conservation of the Lascaux cave (Malaurent et al. 2006; Lacanette et al. 2009) and the determination of factors affecting cave climates for hibernating bats (Perry 2013).

This work presents the results of the study of climatic parameters in the Petites Dales cave, a single-entrance cave in Normandy (France). For the first time, a precise measurement of airflow at different locations and longterm measurements of temperature, weight of water vapour and quantification of air properties were realised. This study provided for the first time evidence of daily airflow inversion.

Our study demonstrates clearly that the cave atmospheres are much more dynamic than previously considered. The study assessed the thermodynamic and kinetic aspects of outside air / inside air interaction to explain spatial, short-term and long-term variations of the cave's atmosphere. This study revealed the existence of different airflow regimes and thus of thermal exchanges between inside and outside air.
Two main ventilation modes were observed, inflow can enter from the ceiling or from the floor depending on the outside-inside difference of weight of vapour in air. Notice that during transition periods, alternation of both ventilation modes occurs.

Nevertheless, it is important to emphasize that the internal climate of the Petites-Dales cave, especially at the entrance, does not behave entirely as observed in similar studies of other caves; the thermodynamics are controlled by local Rayleigh-Bénard convection close to the entrance, which leaves uncertainties for the other part of the cave and suggests further research is required.

Anyway, this circulation can be very important for caves with one entrance or with extremely small entrances, because it can be the only process capable of connecting internal and external atmospheres and, therefore, the chemical composition of cave air.

Based on an increased understanding of the importance of cave circulation for karst processes, we believe that the results of this study may be of interest for micro climatologists, karstologists, speleologists, and environmentalists.

\section{ACKNOWLEDGMENT}

R. Vincent, Normandy University, UMR 6634 CNRS, University of Rouen is gratefully acknowledged for pro- viding computer facilities. M. Skinner is gratefully acknowledged for improving the proof reading. 


\section{REFERENCES}

Aref, H., 1987: Finger, bubble, tendril, spike - an essay on the morphology and dynamics of interfaces in fluid.- Fluid Dynamics Transactions, 13, 24-54.

Atkinson, T.C., Smart, P.L. \& T.M.L. Wigley, 1983: Climate and natural radon levels in Castleguard Cave, Columbia Icefields, Alberta, Canada.- Arctic and Alpine Research, 15, 4, 487-502. DOI: https:// dx.doi.org/10.2307/1551235.

Badino, G., 1995: Fisica Del Clima Sotterraneo.- Istituto Italiano di speleologia, pp. 137, Bologna.

Badino, G., 2004: Cave temperatures and global climatic change.- International Journal of Speleology, 33, 1, 103-113. DOI: http://dx.doi.org/10.5038/1827-806X.33.1.10.

Badino, G., 2010: Underground meteorology- "what's the weather underground?".- Acta Carsologica, 39, 3, 427-448. DOI: http://dx.doi.org/10.3986/ ac.v39i3.74.

Badino, G., Calaforra, J.M., Forti, P., Garofalo, P. \& L. Sanna, 2011: The present day genesis and evolution of cave minerals inside the Ojo de la Reina Cave (Naica Mine, Mexico).- International Journal of Speleology, 40, 2, 125-131. DOI: http://dx.doi. org/10.5038/1827-806X.40.2.5.

Baker, A. \& I.J. Fairchild, 2012: Drip Water Hydrology and Speleothems.- Nature Education Knowledge, 3, 10, paper 16 .

Bergé, P. \& M. Dubois, 1984: Rayleigh-bénard convection.- Contemporary Physics, 25, 6, 535-582. DOI: http://dx.doi.org/10.1080/00107518408210730.

Behringer, R.P. \& G. Ahlers, 1982: Heat transport and temporal evolution of fluid flow near the RayleighBénard instability in cylindrical containers.- Journal of Fluid Mechanics, 125, 219-258. DOI: https:// doi.org/10.1017/S0022112082003322.

Bögli, A., 1980: Karst Hydrology and Physical Speleology.- Springer, pp. 284, Berlin. DOI: https://doi. org/10.1007/978-3-642-67669-7.

Borsato, A., Frisia, S. \& R. Miorandi, 2015: Carbon dioxide concentration in temperate climate caves and parent soils over an altitudinal gradient and its influence on speleothem growth and fabrics.- Earth Surface Processes and Landforms, 40, 9, 1158-1170. DOI: https://dx.doi.org/10.1002/esp.3706.

Buecher, R.H., 1977: Factors influencing the temperature of Arizona caves.- Unpublished report for Arizona Regional Association.

Buecher, R.H., 1999: Microclimate study of Kartchner caverns, Arizona.- Journal of Cave and Karst Studies, 61, 2, 108-120.
Cigna, A.A., 2002: Modern trend in cave monitoring.Acta Carsologica, 31, 1, 35-54. DOI: https://doi. org/10.3986/ac.v31i1.402.

Cropley, J.B., 1965: Influence of surface conditions on temperatures in large cave systems.- Bulletin of the National Speleological Society, 27, 1, 1-10.

Davies, W.E., 1969: Meteorological observations in Martens Cave, West Virginia.- Bulletin of the National Speleological Society, 22, 1, 92-100.

De Freitas, C.R., Littlejohn, R.N., Clarkson, T.S. \& I.S. Kristament, 1982: Cave climate: assessment of airflow and ventilation.- Journal of Climatology, 2, 4, 383-397. DOI: https://dx.doi.org/10.1002/ joc.3370020408.

De Freitas, C.R. \& R.N. Littlejohn, 1987: Cave climate: assessment of heat and moisture exchange.- Journal of Climatology, 7, 6, 553-569. DOI: https://dx.doi. org/10.1002/joc.3370070604.

Faimon, J., Troppová, D., Baldík, V. \& R. Novotný, 2012: Air circulation and its impact on microclimatic variables in the Císařská Cave (Moravian Karst, Czech Republic).- International Journal of Climatology, 32, 4, 599-623. DOI: https://dx.doi.org/10.1002/ joc. 2298 .

Faimon, J. \& M. Lang, 2013: Variances in airflows during different ventilation modes in a dynamic U-shaped cave.- International Journal of Speleology, 42, 2, 115-122. DOI: http://dx.doi.org/10.5038/1827-806X.42.2.3.

Fairchild, I.J., Smith, C.L., Baker, A., Fuller, L., Spötl, C., Mattey, D. \& F. McDermott, 2006: Modification and preservation of environmental signals in speleothems.- Earth-Science Reviews, 75, 1-4, 105-153. DOI: https://doi.org/10.1016/j. earscirev.2005.08.003.

Fairchild, I.J. \& A. Baker, 2012: Speleothem Science: From Process to Past Environments.- John Wiley \& Sons Ltd, pp. 450, Chichester. DOI: https://dx.doi. org/10.1002/9781444361094.ch4.

Fernández-Cortés, A., Calaforra, J.M., Sánchez-Martos, F. \& J. Gisbert, 2006: Microclimate processes characterization of the giant Geode of Pulpí (Almería, Spain): technical criteria for conservation.- International Journal of Climatology, 26, 5, 691-706. DOI: https://dx.doi.org/10.1002/joc.1269.

Furbish, D.J., 1997: Fluid physics in geology: an introduction to fluid motions on Earth's surface and within its crust.- Oxford University Press, pp. 496, New York. 
Gamble, D.W., Dogwiler, J.T. \& J. Mylroie, 2000: Field assessment of the microclimatology of tropical flank margin caves.- Climate Research, 16, 1, 37-50. DOI: https://dx.doi.org/10.3354/cr016037.

Geiger, R., 1961: Das Klima der bodennahen Luftschicht.- Anzeiger für Schädlingskunde, 34, 10, 159-159.

Gillieson, D., 1996: Caves: Processes, development and management.- Blackwell Publishers, pp. 336, Cambridge.

Hasegawa, W., Sawagaki, T., Hirakawa, K., Watanabe, Y. \& T. Tagami, 2014: Description and environmental monitoring of Hokkai Cave in northern Japan.Cave and Karst Science, 41, 1, 3-12.

Hill, C.A., 1987: Geology of Carlsbad Cavern and other caves in the Guadalupe Mountains, New Mexico and Texas.- Bulletin 117, New Mexico Bureau of Mines \& Mineral Resources, pp. 150, New Mexico.

Jeannin, P.Y., 1991: Températures dans la zone vadose du karst.- In: Actes du 9è Congrès national de la SSS, 1991, 71-76, Charmey.

Jernigan, J.W. \& R.J. Swift, 2001: A mathematical model of air temperature in Mammoth Cave, Kentucky.Journal of cave and karst studies, 63, 1, 3-8.

Julien, K., Knobloch, E., Rubio, A.M. \& G.M. Vasil, 2012: Heat transport in low-Rossby-number RayleighBénard convection.- Physical review letters, 109, 25, 254503.

Koschmieder, E.L. \& S.G. Pallas, 1974: Heat transfer through a shallow horizontal convecting fluid layer.International Journal of Heat and Mass Transfer, 17, 9, 991-1002. DOI: https://doi.org/10.1016/00179310(74)90181-1.

Lacanette, D., Vincent, S., Sarthou, A., Malaurent, P. \& J.P. Caltagirone, 2009: An Eulerian/Lagrangian method for the numerical simulation of incompressible convection flows interacting with complex obstacles: Application to the natural convection in the Lascaux cave.- International Journal of Heat and Mass Transfer, 52, 11-12, 2528-2542. DOI: https:// doi.org/10.1016/j.ijheatmasstransfer.2008.12.028.

Lacanette, D., Large, D., Ferrier, C., Aujoulat, N., Bastian, F., Denis, A. \& C. Saiz-Jimenez, 2013: A laboratory cave for the study of wall degradation in rock art caves: an implementation in the Vézère area.- Journal of Archaeological Science, 40, 2, 894-903. DOI: https://doi.org/10.1016/j.jas.2012.10.012.

Lecoq, N., Magne, L., Rodet, J., Chédeville, S., Fournial, C. \& J.P. Viard, 2014: Etude climatique d'une grotte de la craie à une entrée: exemple de la grotte des Petites Dales (Normandie, France).- In: $18^{\text {ème }}$ Journées de Spéléologie Scientifique, Nov 2014, Han sur Lesse.
Liñán, C. \& Y. del Rosal, 2015: Natural Ventilation of Karstic Caves: New Data on the Nerja Cave (Malaga, S of Spain).- In: Andreo, B. et al. (eds.) Hydrogeological and Environmental Investigations in Karst Systems. Springer, pp. 505-511, Berlin.

Lir, J.T. \& T.F. Lin, 2001: Visualization of roll patterns in Rayleigh-Bénard convection of air in a rectangular shallow cavity.- International Journal of Heat and Mass Transfer, 44, 15, 2889-2902. DOI: https://doi. org/10.1016/S0017-9310(00)00340-9.

Lismonde, B., 2002: Climatologie du monde souterrain. Tome 2, Aérologie des Systèmes Karstiques.- Edition du Comité Départemental de Spéléologie de l'Isère, pp. 361, Grenoble.

Lismonde, B., 2005: La sécheresse 2003 et les mesures de température au Trou qui Souffle de Méaudre: rôle du flux géothermique.- Karstologica, 45-46, 63-66.

Luetscher, M. \& P.Y. Jeannin, 2004: Temperature distribution in karst systems: the role of air and water fluxes.- Terra Nova, 16, 6, 344-350. DOI: https:// dx.doi.org/10.1111/j.1365-3121.2004.00572.x.

Luetscher, M., Lismonde, B. \& P.Y. Jeannin, 2008: Heat exchanges in the heterothermic zone of a karst system: Monlesi cave, Swiss Jura Mountains.- Journal of Geophysical Research, 113, F2, F02025.

Maas, W.J.P.M., Rindt, C.C.M. \& A.A. van Steenhoven, 2003: The influence of heat on the 3D-transition of the von Karman vortex street.- International Journal of Heat and Mass Transfer, 46, 16, 3069-3081. DOI: http://dx.doi.org/10.1016/S0017-9310(03)00076-0.

Magne, L., Lecoq, N., Rodet, J., Chédeville, S., Fournial, C. \& J.P. Viard, 2015: Les inversions des circulations d'air dans une grotte de la craie à une entrée. Exemple de la grotte des Petites Dales (Normandie, France).- In: $19^{\text {ème }}$ Journées de Spéléologie Scientifique, Nov 2015, Han sur Lesse.

Malaurent, P., Brunet, J., Lacanette, D. \& J.P. Caltagirone, 2006: Contribution of numerical modelling of environmental parameters to the conservation of prehistoric cave paintings: the example of Lascaux Cave.- Conservation and management of archaeological sites, 8, 2, 59-76.

Mattey, D.P., Lowry, D., Duffet, J., Fisher, R., Hodge, E. \& S. Frisia, 2008: A 53 year seasonally resolved oxygen and carbon isotope record from a modern Gibraltar speleothem: Reconstructed drip water and relationship to local precipitation.- Earth and Planetary Science Letters, 269, 80-95. 
Mattey, D.P., Fairchild I.J., Atkinson, T.C., Latin, J.P., Ainsworth, M. \& R. Durell, 2010: Seasonal microclimate control of calcite fabrics, stable isotopes and trace elements in modern speleothem from St. Michaels Cave, Gibraltar.- In: Pedley, H.M. \& M. Rogerson (eds.) Tufas and Speleothems: Unravelling the Microbial and Physical Controls. Geological Society Special Publication 336, pp. 323-344, London.

Mattey, D.P., Fisher, R., Atkinson, T.C., Latin, J.P., Durrell, R., Ainsworth, M., Lowry, D. \& I.J. Fairchild, 2013: Methane in underground air in Gibraltar karst.- Earth and Planetary Science Letters, 374, 71-80.

McLean, J.S., 1971: The microclimate in Carlsbad Caverns, New Mexico.- U.S. Geological Survey, Open File Report 71-198.

Météo-France (French meteorological service), 2017: Precipitation data.- [Online] Available from: https://donneespubliques.meteofrance.fr/ [Accessed 3rd November 2017].

Michie, N.A., 1984: Determination of the causes of air flow in Coppermine Cave, Yarrangobilly.- Helictite, $22,1,21-30$.

Moore, G.W. \& G.N. Sullivan, 1978: Speleology: The Study Of Caves.- Zephyrus Press, pp. 150, Teaneck, N.Y.

Mueschke, N.J., Andrews, M.J. \& O. Schilling, 2006: Experimental characterization of initial conditions and spatio-temporal evolution of a small-Atwoodnumber Rayleigh-Taylor mixing layer.- Journal of Fluid Mechanics, 567, 27-63. DOI: https://doi. org/10.1017/S0022112006001959.

Perry, R.W., 2013: A review of factors affecting cave climates for hibernating bats in temperate North America.- Environmental Reviews, 21, 1, 28-39. DOI: https://doi.org/10.1139/er-2012-0042.

Peyraube, N., Lastennet, R., Villanueva, J.D., Houillon, N., Malaurent, P. \& A. Denis, 2017: Effect of diurnal and seasonal temperature variation on Cussac cave ventilation using $\mathrm{CO}_{2}$ assessment.- Theoretical and Applied Climatology, 129, 3-4, 1045-1058. DOI: https://doi.org/10.1007/s00704-016-1824-8.

Picard, A., Davis, R.S., Gläser, M. \& K. Fujii, 2008: Revised formula for the density of moist air (CIPM2007).- Metrologia 45, 2, 149-155.

Poulson, T.L. \& W.B. White, 1969: The cave environment.- Science, 165, 3897, 971-981. DOI: https:// doi.org/10.1126/science.165.3897.971.

Ravbar, N. \& J. Kosutnik, 2014: Variations of karst underground air temperature induced by various factors (Cave of Zupanova jama, Central Slovenia).- Theoretical and Applied Climatology, 116, 1-2, 327-341. DOI: https://doi.org/10.1007/s00704-013-0955-4.
Lord Rayleigh, 1882: Investigation of the Character of the Equilibrium of an Incompressible Heavy Fluid of Variable Density.- Proceedings of the London Mathematical Society, 14, 170-177. DOI: https:// doi.org/10.1112/plms/s1-14.1.170.

Lord Rayleigh, 1916: On convection currents in a horizontal layer of fluid, when the higher temperature is on the under side. The London, Edinburgh, and Dublin Philosophical Magazine and Journal of Science, Series 6, 32, 529-546. DOI: http://dx.doi. org/10.1080/14786441608635602.

Rodet, J., Laignel, B., Brocard, G., Dupuis, E., Massei, N. \& J.P. Viard, 2006: Contribution of a sedimentary study to the karstic evolution concept of a chalk cave of the western Paris basin (Normandy, France).- Geologica Belgica, 9, 3-4, 287-296.

Rodet, J. \& J.P. Viard, 2009 : La grotte des Petites Dales, patrimoine normand ! pas normal ?.- Spelunca, 114, 28-34.

Rodet, J., Willems, L., Brown, J., Ogier-Halim, S., Bourdin, M. \& J.P. Viard, 2009: Morphodynamic incidences of the trepanning of the endokarst by solution pipes. Examples of chalk caves in Western Europe (France and Belgium).- In: White, W.B. (ed.) Proceedings of the $15^{\text {th }}$ International Congress of Speleology, 19 th $^{\text {th }} 6^{\text {th }}$ July 2009, Kerrville, Texas. International Union of Speleology, 1657-1661, Kerrville, Texas.

Rodet, J., Magne, L. \& J.P. Viard, 2013: Ceiling channel and input karst. Example of the Petites Dales Cave, Normandy, France.- In: Filippi, M. \& P. Bosák (eds.) Proceedings of the $16^{\text {th }}$ International Congress of Speleology, $21^{\text {st }}-28^{\text {th }}$ July 2013, Brno. International Union of Speleology, 126-131, Brno.

Sánchez-Cañete, E.P., Serrano-Ortiz, P., Domingo, F. \& A.S. Kowalski, 2013: Cave ventilation is influenced by variations in the $\mathrm{CO}_{2}$-dependent virtual temperature.- International Journal of Speleology, 42, 1, 1-8. DOI: http://dx.doi.org/10.5038/1827-806X.42.1.1.

Shindo, S., 2005: Micrometeorological modeling of an idealized cave and application to Carlsbad Cavern, NM.- PhD thesis. New Mexico Institute of Mining and Technology, pp. 244.

Spötl, C., Fairchild, I.J. \& A.F. Tooth, 2005: Cave air control on dripwater geochemistry, Obir Caves (Austria): implications for speleothem deposition in dynamically ventilated caves. Geochimica et Cosmochimica Acta, 69, 10, 2451-2468. DOI: https:// doi.org/10.1016/j.gca.2004.12.009. 
Talukdar, P., Iskra, C.R. \& C.J. Simonson, 2008: Combined heat and mass transfer for laminar flow of moist air in a $3 \mathrm{D}$ rectangular duct: CFD simulation and validation with experimental data.- International Journal of Heat and Mass Transfer, 51, 11-12, 3091-3102. DOI: https://doi.org/10.1016/j. ijheatmasstransfer.2007.08.034.

Taylor, G.I., 1950: The instability of liquid surfaces when accelerated in a direction perpendicular to their planes.- Proceedings of the Royal Society of London. Series A, Mathematical and Physical Sciences, 201, 192-196. DOI: https://doi.org/10.1098/ rspa. 1950.0052.

Tuttle, M.D. \& D.E. Stevenson, 1978: Variations in the cave environment and its biological implications.In: Zuber, R., Chester, J., Gilbert, S. \& D. Rhodes (eds.) National Cave Management Proceedings, $3^{\text {rd }}-7^{\text {th }}$ October 1977, Big Sky, Mont. Speleobooks, 180-121, Albuquerque, N.M.
Vieten, R., Winter, A., Warken, S.F., Schröder-Ritzrau, A., Miller, T.E. \& D. Scholz, 2016: Seasonal temperature variations controlling cave ventilation processes in Cueva Larga, Puerto Rico.- International Journal of Speleology, 45, 3, 259-273. DOI: http:// dx.doi.org/10.5038/1827-806X.45.3.1983.

Wigley, T.M.L. \& C. Brown, 1971: Geophysical Applications of Heat and Mass Transfer in Turbulent Pipe Flow.- Boundary-Layer Meteorology, 1, 3, 300-320. DOI: https://doi.org/10.1007/BF02186034.

Wilson, J.L., 2004: Conceptual model: unpublished notes on model of convection in cavities (e.g. caves), New Mexico Tech. 